\title{
The Application of Formative Evaluation Strategies in College English Classroom from the Perspective of Teacher Questioning
}

\author{
Xiaoping Mai \\ School of Foreign Studies, Lingnan Normal University, Zhanjiang, China \\ Email: pearlmai@126.com
}

How to cite this paper: Mai, X. P. (2021). The Application of Formative Evaluation Strategies in College English Classroom from the Perspective of Teacher Questioning. Open Journal of Modern Linguistics, 11, 873-882. https://doi.org/10.4236/ojml.2021.116067

Received: October 27, 2021

Accepted: November 27, 2021

Published: November 30, 2021

Copyright ( 2021 by author(s) and Scientific Research Publishing Inc. This work is licensed under the Creative Commons Attribution International License (CC BY 4.0).

http://creativecommons.org/licenses/by/4.0/

\begin{abstract}
Formative evaluation emphasizes the active participation of learners and is conducive to continuous observation, evaluation, monitoring and adjustment of the learning process. Through the classroom observations of four college English teachers and the analysis of the interview materials, it is found that there are differences in the types of questions and the types of answers. The article emphasizes effective questioning in the classroom that can promote students' learning, and at the same time provides insights on how teachers can make better use of teacher questioning as a formative evaluation strategy.
\end{abstract}

\section{Keywords}

Formative Evaluation, Teacher Questioning, College English Teaching

\section{Introduction}

Teaching evaluation is an important part of college English teaching. It can not only help teachers better understand students' learning conditions, thereby improving their own teaching, but also help students adjust learning strategies to improve learning efficiency. Teaching evaluation includes not only summative evaluation represented by standardized tests, but also formative evaluation that focuses on the learning process (Leung \& Mohan, 2004). Formative evaluation is the behavior taken by teachers and students that can obtain feedback information and guide teaching. The biggest difference between formative evaluation and summative evaluation lies in their different effects on teaching. At the same time, progressive formative evaluation that provides students with appropriate feedback can have a powerful and positive impact on teaching (Black \& Wiliam, 1998; Torres, 2019). By studying the relevant literature on the formative evalua- 
tion of foreign language teaching published in 18 foreign language journals in China from 2002 to 2016, Yuan and Shu (2017) found that although the research on formative evaluation of foreign language teaching had shown diversified perspectives and distinctive research characteristics, we should at the same time learn from the advanced methods of formative evaluation research in other countries to further explore the problems in domestic evaluation research and innovate the research content of formative evaluation. This article attempts to use the method of empirical research to explore how to tap the learning potential of students by means of formative evaluation in the English classroom from the perspective of teacher questioning.

\section{Related Research of Classroom Evaluation Strategies}

Formative evaluation is an important element of effective teaching. It requires teachers to collect information about students' learning conditions, and analyze and use this information. Black and Wiliam (2009) pointed out that judging whether an evaluation is formative or not mainly depends on whether the evidence materials about the student's academic performance can be obtained and explained, and whether these materials can be used by teachers, learners or their peers to make better decisions for future teaching. It can be seen that formative evaluation and classroom teaching are closely related. As Rea-Dickins (2001) pointed out, "good classroom teaching often embeds evaluation strategies, especially some informal evaluation strategies." Carless (2011) listed seven formative evaluation strategies, such as sharing learning goals and success criteria, teacher questioning, peer evaluation, self-evaluation, teacher feedback, etc., and pointed out that these strategies reflect the characteristics of excellent classroom teaching, because students, peers or teachers can use these strategies to grasp the evidence of the learning process.

Teacher questioning is a widely used teaching strategy. It can help teachers collect important information about the current learning level of students, so that teachers can better adjust their teaching strategies to promote students' learning. Teacher questioning has a positive effect on cultivating students' critical thinking ability (Black et al., 2003; Chen, 2019; Nashruddin \& Rahmawati Ningtyas, 2020). Teacher questioning generally follows the procedures: teacher initiation-student response-teacher feedback/evaluation (IRF/E for short) (Mehan, 1979). It is worth noting that teacher questioning cannot be used as an evaluation tool under any circumstances. As a formative evaluation tool, teacher questioning should follow the three points: First, the questions asked by the teacher should help students understand what they are learning; the second is that the student response induced by the teacher should represent the student's thinking level, so as to help the teacher make subsequent decisions and adjustments; the third is that teachers should take meaningful interventions to promote students to achieve their learning goals (Black et al., 2003; Hill \& McNamara, 2012). In short, in order to make teacher questioning a formative evaluation tool, teachers should check the entire process of classroom questioning and ensure that each 
step cannot be separated from the purpose of learning.

Teachers' classroom questions have different classification standards. Richards and Lockhart (1994) divide teachers' classroom questions into procedural questions, convergent questions and divergent questions. The first type refers to questions related to classroom routines and management, and the other two refer to questions raised in response to learning content. Convergent questions tend to allow students to review what they have learned before and give similar or short answers, while divergent questions encourage students to give different answers. Therefore, they pose a higher-level thinking challenge to students.

In terms of formative evaluation and second language classroom interaction research, many scholars have conducted research on strategies such as peer and self-evaluation, teachers' classroom questioning methods, and teacher feedback (e.g. Black et al., 2003; Hu et al., 2004; Ruiz-Primo \& Furtak, 2006), but there are relatively few studies on teacher questioning as a formative evaluation tool. This research conducted a study on the classroom questioning of four college English teachers, aiming to understand how teachers use questioning as a formative evaluation strategy to promote students' learning. Specifically, it mainly includes the following three aspects of research questions: 1) What kinds of questions are raised by teachers in class? Are they conducive to students' learning? 2) What kinds of reaction do teachers' questions elicit from the students? Do they represent the thinking level of students? 3) What will teachers do after getting the response from the students? Do they promote students' learning?

\section{Methods}

\subsection{Participants}

The objects of this research were four college English teachers from a university in Guangdong Province, among whom Teacher A and Teacher B were young teachers who were in their first five years of tertiary teaching have been working for less than five years, and the other two teachers $C$ and D were middle-aged teachers with more than fifteen years' teaching experience. The classes observed were courses given to non-English majors. The student age ranged from 18 to 20. The English lessons all aimed at developing students' English proficiency and communicative competence by carrying out activities of listening, speaking, reading and writing in class.

\subsection{Data Collection}

This research mainly used classroom observations, classroom videos and interviews to obtain data. Among them, classroom observation lasts for one semester, mainly observing teachers' questioning strategies and students' response status in classroom interaction. In order to more accurately record and analyze the classroom interaction between teachers and students, the researcher made a 90-minute video of each teacher's comprehensive English classroom during this period. Then, the researcher invited the students to participate in semi-structured 
interviews in small groups. A total of twenty students participated in four interviews each with a duration of one hour. The four teachers were also invited individually for the interviews. The interview questions for teachers and students followed similar patterns, for example: "What types of questions do you/teachers usually ask?" "What types of questions do you prefer and why?" "How do you/teachers react to the answer when it is (in)correct?"

\subsection{Data Analysis}

Data collected in this research were analyzed in a qualitative approach. According to the classification method of Richards \& Lockhart (1994) and Hattie \& Timperley (2007) on teachers' questions and students' responses, the researcher coded the transcription of the classroom recordings and interview recordings, and then formed themes. When conducting data analysis, the researcher analyzed and compared the statistical results of the classroom recordings with the relevant data of the interviews, so as to more accurately describe the relevant situation of teachers' questions in English classrooms and enhance the reliability of the research results.

\section{Results and Discussion}

Table 1 and Table 2 present some of the main characteristics of the four college English teachers' classroom questions: First, the number of young teachers' questions in the classroom is relatively large. Second, most of the teachers' classroom questions are convergent questions (79\%). Procedural questions and divergent questions accounted for $12 \%$ and $9 \%$ respectively. Third, from the perspective of the answers to the questions, 36\% of the questions were answered collectively, and $28 \%$ of the questions were answered voluntarily by the students. The teacher's roll call accounted for $25 \%$, and the other $11 \%$ of the questions were answered by teachers themselves without the students' responses.

\subsection{Teachers' Questions Promote Students' Further Learning from Different Cognitive Levels}

The results in Table 1 show that the question types are mainly convergent questions. The teachers mostly ask questions around the background knowledge of

Table 1. Types of questions.

\begin{tabular}{cccccccc}
\hline \multirow{2}{*}{ Name } & \multirow{2}{*}{$\begin{array}{c}\text { Total number of questions/ } \\
\text { each class (90 minutes) }\end{array}$} & \multicolumn{2}{c}{ Procedural questions } & \multicolumn{2}{c}{ Convergent questions } & \multicolumn{2}{c}{ Divergent questions } \\
\cline { 3 - 7 } & Number & Percentage & Number & Percentage & Number & Percentage \\
\hline Teacher A & 98 & 12 & $12 \%$ & 80 & $82 \%$ & 6 & $6 \%$ \\
Teacher B & 103 & 17 & $17 \%$ & 68 & $66 \%$ & 18 & $17 \%$ \\
Teacher C & 73 & 7 & $10 \%$ & 61 & $83 \%$ & 5 & $7 \%$ \\
Teacher D & 69 & 6 & $9 \%$ & 60 & $87 \%$ & 3 & $4 \%$ \\
Total & 343 & 42 & $12 \%$ & 269 & $79 \%$ & 32 & $9 \%$ \\
\hline
\end{tabular}


Table 2. Types of responses.

\begin{tabular}{|c|c|c|c|c|c|c|c|c|c|}
\hline \multirow{2}{*}{ Name } & \multirow{2}{*}{$\begin{array}{l}\text { Total number of } \\
\text { questions/each } \\
\text { class (90 minutes) }\end{array}$} & \multicolumn{2}{|c|}{ Collective answer } & \multicolumn{2}{|c|}{ Voluntary answer } & \multicolumn{2}{|c|}{ Teacher roll call } & \multicolumn{2}{|c|}{ Teacher answers } \\
\hline & & Number & Percentage & Number & Percentage & Number & Percentage & Number & Percentage \\
\hline Teacher A & 98 & 29 & $30 \%$ & 34 & $35 \%$ & 25 & $25 \%$ & 10 & $10 \%$ \\
\hline Teacher B & 103 & 42 & $41 \%$ & 23 & $22 \%$ & 26 & $25 \%$ & 12 & $12 \%$ \\
\hline Teacher C & 73 & 21 & $29 \%$ & 26 & $36 \%$ & 17 & $23 \%$ & 9 & $12 \%$ \\
\hline Teacher D & 69 & 30 & $43 \%$ & 14 & $20 \%$ & 19 & $28 \%$ & 6 & $9 \%$ \\
\hline Total & 343 & 122 & $36 \%$ & 97 & $28 \%$ & 87 & $25 \%$ & 37 & $11 \%$ \\
\hline
\end{tabular}

the text, the content of the text, the analysis of the text structure and the language points of the text, and the answers to the questions are often what the teachers already know or expect. In interviews, the students expressed different views on the convergent questions. Some students said that they had become accustomed to this type of questioning method since middle school, and said that they "are not interested in this kind of questions with standard answers, and don't feel any new or challenging". However, some students think that these questions are "very necessary" because they can "check for omissions" on what they have learned. Some students said that they liked the teacher to ask questions about the background knowledge of the text, because on the one hand, it could broaden their knowledge, and on the other hand, it would pave the way for their subsequent learning. Although the convergent questions are generally at a low level of cognition, teachers can use these questions to check students' mastery of what they are learning, and adjust their teaching in time to further promote students' learning.

Although the proportion of divergent questions raised by teachers in the classroom is not high in general, among the four research subjects, the divergent questions raised by Teacher B in the classroom far exceed those of the other three teachers, accounting for as much as $17 \%$. Divergent questions are more challenging to students' cognitive level. Students often need to review, analyze, synthesize, and evaluate what they have learned before they can find a way to solve the problem. At the same time, the openness of divergent questions stimulates students to express their true ideas from different angles. In an interview, a student in Teacher B's class said: "I particularly like the teacher asking questions like 'What do you think about...? Why?' because we can freely express our own views on a certain issue, sometimes the teacher will be refuted by us too, which is so cool." In addition to promoting students' cognitive development, divergent questions can also create a sense of psychological security for students. As a student who claimed to be a "study slacker" said: "I like teachers to ask divergent questions because the answer is not fixed. I can express my views freely in class, and I don't feel pressure in front of a straight A student."

Divergent questions have a very good role in promoting the development of students' cognitive level and thinking ability. As Richards and Lockards (1994) 
said, divergent questions could encourage students to "engage in higher-level thinking". Students must not only sort out the knowledge they have learned, but also apply it to a new context, combining their own thinking and judgment to find a solution to the problem. In addition, the openness and safety of divergent questions can stimulate the willingness and enthusiasm of students to share personal views in the classroom, thereby enhancing students' classroom participation.

\subsection{Answers Based on Group Discussion Can Better Reflect Students' Thinking Level}

Judging from the answers to the questions, Table 2 shows that most of the questions are answered collectively by students (36\%). When asked about his views on the collective response, Teacher D thought that it was because the questions were simpler, and more importantly, it could save time and maintain the interactive atmosphere in the classroom. In the interview, some students thought that collective answers seemed "safer" because it was not easy for teachers to distinguish which students gave which answers, and they felt that they "would not be ashamed." Holliday (1994) pointed out that this collective response method can make the classroom present the illusion of superficial activity and learning progress. To some extent, the collective answer does not reflect the true level of students' thinking.

However, it is worth pointing out that Table 2 shows that the classroom questions of two teachers have been voluntarily answered by most of the students (respectively $35 \%$ and $36 \%$ ). These classroom questions include convergent and divergent questions. Teacher $\mathrm{A}$ and Teacher $\mathrm{C}$ generally give students time for pairing or group discussion after asking questions in class. Students can communicate with their peers during this period, and then choose a representative to raise their hands to answer. When Teacher $\mathrm{C}$ was asked in an interview why the "question-discussion-answer" format was adopted in her classroom, she believed that giving students time for pairing or group discussions would allow students to fully think about the problem from different perspectives, and at the same time can make the answer to the question more focused. This method has also been recognized and welcomed by students. In the interview, one student said, "Group discussion allows me to organize my own answers and avoid rushing answers that lack logic. I am reluctant to answer questions because I am afraid that my answer appears very naive and ignorant, but after the group discussion, I no longer have such worries and am willing to share my answer with everyone."

The answer after the group discussion reflects the students' thinking level to a certain extent, because the students can continuously modify and perfect their original ideas when discussing with their peers, making their thinking more in-depth. At the same time, students will be more willing to answer questions after discussing with their peers, and psychologically they will be more relaxed and confident. The research of Astrid et al. (2019) also found that when teachers 
raise divergent questions with higher cognitive challenges in the classroom, students tend to remain silent, and the classroom atmosphere falls into an embarrassing stalemate. Therefore, through the "question-discussion-answer" approach, teachers can fully mobilize the enthusiasm of students to participate in the classroom, so that students' thinking level can be continuously improved in the collision of ideas.

\subsection{After-School Task-Based Question Inquiry Is More Helpful to Promote Students' Learning}

When the question cannot be answered by the students, Teacher D's approach is generally to give the answer by the teacher himself. He believed that this could save time in the classroom and make classroom activities go smoothly and "not to be cold." In the interview, some students also said that the teacher's direct answer can alleviate their "pain of thinking and meditation" and at the same time avoid the "fear" of being named by the teacher to answer questions. Although the teacher's answer is helpful to alleviate the temporary silence in the classroom, it is difficult to effectively promote the learning of students. Students who are accustomed to this method are prone to lose their initiative and spirit of inquiry in learning, which will have a great negative impact on their future learning.

For questions that cannot be answered, Teacher $\mathrm{C}$ generally leaves them as homework for students. She said: "When students do not respond, I used to tell them the answer directly, but I found that they would forget it soon. So now I will ask them to check the information after class, and then ask one or two groups to send representatives to explain to everyone in the next class. Through the method of 'teaching', they have a deeper and firmer grasp of knowledge."

In the interview, the students of Teacher $\mathrm{C}$ also agreed with this approach, believing that the teacher assigned them to explore the answers to the questions after class, so that they could have more time for further in-depth understanding. More importantly, they were actively preparing lessons in order to win the "Excellent Performance Award" in the next classroom presentation. From this point of view, when there is no response from the students, Teacher C's approach can make students aware of their own shortcomings on the one hand, thereby inspiring students' desire and motivation for further exploration; on the other hand, it can cultivate students' sense of responsibility for learning. Students must realize that teachers are not pure indoctrinators of knowledge, and they have to work together with their team members to better understand and master knowledge. Fan (2005) pointed out that when students use "I don't know" to avoid answering a question, teachers can break this deadlock by repeating the question, changing the wording of the question, or narrowing the scope of the question.

\section{Conclusion}

This article explores the use of formative evaluation strategies in college English 
classrooms from the perspective of teacher questioning. On the whole, teachers raise more convergent questions than divergent ones in the classroom, and the research results are basically consistent with those of previous scholars (e.g. Jiang, 2014; Milawati, 2017). Black et al. (2003) pointed out that high-quality questions raised by teachers in the classroom can become an important means of classroom evaluation. Although convergent questions do not require students' cognitive level as high as those of divergent questions, teachers can use these questions to check students' mastery of what they are learning, so as to check for omissions and adjust their teaching in time. Different from convergent questions, divergent questions stimulate the thinking ability of students on a higher cognitive level, which can cultivate the spirit of continuous inquiry of students. In view of this, teachers can assign those questions that cannot be solved in class as homework for students and allow them to conduct deep learning through group exploration after class, so as to better cultivate their learning autonomy and sense of responsibility.

The implications of this research for teaching are mainly as follows: First, whether teachers' classroom questions are convergent or divergent, the essence should be to see whether these questions can stimulate students' interest in learning and promote their learning. The teachers' questions should be slightly higher than the students' current thinking level, so that students have the enthusiasm for inquiry and confidence in success. Second, teachers should try their best to mobilize the enthusiasm of students to participate in classroom activities. After teachers raise questions, students should be given enough time for group discussion. Students will be more willing and confident to answer questions after discussing with their peers. Third, teachers should cultivate students' sense of responsibility for their own learning. They can take the questions that students cannot answer temporarily as the starting point for further learning and lead students to explore new knowledge and become really good learners.

\section{Acknowledgements}

This paper and the study are funded by: Fund Project 1: College English teaching reform project of Guangdong province "Research and Practice of College Academic English Teaching Model Based on Functional Language Analysis" (Project No: YDY-2019-19); Fund Project 2: Research project of Guangdong Education Department "A Study of College English Classroom Ecology Based on the Theory of Ecology of Education (Project No.: 2015GXJK084).

\section{Conflicts of Interest}

The author declares no conflicts of interest regarding the publication of this paper.

\section{References}

Astrid, A., Amrina, R. D., Desvitasari, D., Fitriani, U., \& Shahab, A. (2019). The Power of 
Questioning: Teacher's Questioning Strategies in the EFL Classrooms. Indonesian Research Journal in Education, 3, 91-106. https://doi.org/10.22437/irje.v3i1.6601

Black, P., \& Wiliam, D. (1998). Assessment and Classroom Learning. Assessment in Education: Principles, Policy and Practice, 5, 7-74. https://doi.org/10.1080/0969595980050102

Black, P., \& Wiliam, D. (2009). Developing the Theory of Formative Assessment. Educational Assessment, Evaluation and Accountability, 21, Article No. 5. https://doi.org/10.1007/s11092-008-9068-5

Black, P., Harrison, C., Lee, C., Marshall, B., \& Wiliam, D. (2003). Assessment for Learning: Putting It into Practice. Open University Press.

Carless, D. (2011). From Testing to Productive Student Learning: Implementing Formative Assessment in Confucian-Heritage Settings. Routledge.

Chen, Y. P. (2019). Developing Students' Critical Thinking and Discourse Level Writing Skill through Teachers' Questions: A Sociocultural Approach. Chinese Journal of Applied Linguistics, 42, 141-162. https://doi.org/10.1515/CJAL-2019-0009

Fan, L. H. (2005). Teachers' Bad Classroom Questioning View and Its Improvement Strategies. Educational Science Research, No. 8, 43-45.

Hattie, J., \& Timperley, H. (2007). The Power of Feedback. Review of Educational Research, 77, 81-112. https://doi.org/10.3102/003465430298487

Hill, K., \& McNamara, T. (2012). Developing a Comprehensive, Empirically Based Research Framework for Classroom-Based Assessment. Language Testing, 29, 395-420. https://doi.org/10.1177/0265532211428317

Holliday, A. (1994). Appropriate Methodology and Social Context. Cambridge University Press.

Hu, Q. Q., Nicolson, E., \& Chen, W. (2004). A Survey of Classroom Questioning Patterns of College English Teachers. Foreign Language Journal, No. 6, 22-27.

Jiang, Y. (2014). Exploring Teacher Questioning as a Formative Assessment Strategy. RELC Journal, 45, 287-304. https://doi.org/10.1177/0033688214546962

Leung, C., \& Mohan, B. (2004). Teacher Formative Assessment and Talk in Classroom Context: Assessment as Discourse and Assessment of Discourse. Language Testing, 21, 335-359. https://doi.org/10.1191/0265532204lt287oa

Mehan, H. (1979). Learning Lessons: Social Organization in the Classroom. Harvard University Press. https://doi.org/10.21462/jeltl.v2i2.67

Milawati. (2017). Teacher Questioning as a Formative Assessment Strategy in EFL Context. Journal of English Language Teaching and Linguistics, 2, 117-134.

https://doi.org/10.21462/jeltl.v2i2.67

Nashruddin, N., \& Rahmawati Ningtyas, P. (2020). English as Foreign Language (EFL) Teacher's Questioning Strategies in Classroom Interaction. Utamax: Journal of Ultimate Research and Trends in Education, 2, 5-11. https://doi.org/10.31849/utamax.v2i1.3720

Rea-Dickins, P. (2001). Mirror, Mirror on the Wall: Identifying Processes of Classroom Assessment. Language Testing, 18, 429-462. https://doi.org/10.1177/026553220101800407

Richards, J. C., \& Lockhart, C. (1994). Reflective Teaching in Second Language Classrooms. Cambridge University Press. https://doi.org/10.1017/CBO9780511667169

Ruiz-Primo, M. A., \& Furtak, E. M. (2006). Informal Formative Assessment and Scientific Inquiry: Exploring Teachers' Practices and Student Learning. Educational Assessment, 11, 205-235. https://doi.org/10.1080/10627197.2006.9652991 
Torres, J. (2019). Positive Impact of Utilizing More Formative Assessment over Summative Assessment in the EFL/ESL Classroom. Open Journal of Modern Linguistics, No. 9, 1-11. https://doi.org/10.4236/ojml.2019.91001

Yuan, S. H., \& Shu, D. F. (2017). Research on Formative Assessment in Foreign Language Teaching in China. Foreign Language Teaching Theory and Research, No. 4, 51-58. 